\title{
Evaluation of Our Cases of Foreign Body in Various Anatomical Regions of the Body
}

\author{
Ertugrul Allahverdi (Corresponding author) \\ Kafkas University Department of Orthopedics and Traumatology \\ E-mail:ertugrulallahverdi@hotmail.com \\ Tulay Diken Allahverdi \\ Kafkas University Department of General Surgery
}

\begin{abstract}
Aim: It can be quite difficult to remove foreign bodies located within soft tissue. The location needs to be defined for the procedure to be successful. The aim of this study was to present our cases where a foreign body had been detected and then removed from various anatomical regions.

Material and Method: This article is about the evaluation results of our foreign body cases referred to the Kafkas University Faculty of Medicine from the Family Medicine practices in Kars and the surrounding regions. The charts of 15 patients who had presented to the General Surgery or Orthopedics and Traumatology Departments of the Kafkas University Faculty of Medicine after being referred from the emergency or outpatients departments between November 2015 and July 2019 were retrospectively reviewed. The demographic findings, surgical treatment and results, etiological causes and postoperative complications of the patients were recorded. Follow-up duration was 6 months to 3 years depending on the patient's condition.

Results: There were 8 male and 7 female patients. The mean age was 30.79 years. The symptoms were pain, redness, swelling, itching and serous or purulent discharge for foreign bodies in the hand, foot, femur-tibia soft and bone tissue areas and acute abdomen symptoms in the patient where we found an intra-abdominal foreign body. The imaging methods used were conventional radiography and computed tomography. Treatments included removal of needle from soft tissue, bullet fragment from bone intramedullary tissues and intrauterine device from transverse colon meso. We also observed the rectal passage with feces of an intestinal intraluminal metallic device after it was swallowed. There was only one complication among all our patients and consisted of partial radial nerve damage.

Conclusion: Foreign bodies should be located with imaging methods and removed under sterile conditions in the operating room. Early detection and removal of foreign bodies from anatomical regions are vital.
\end{abstract}

Key Words: Foreign body, Radio-opaque, Soft Tissue

DOI: $10.7176 / \mathrm{JSTR} / 7-04-01$

\section{Introduction}

Foreign bodies that may require removal by surgical intervention may be located in a wide range of areas from the respiratory tract to the subcutaneous soft tissues, bones and the gastrointestinal system $(1,2)$. An estimated 1,500 to 1,600 patients die each year in the US as a result of complications related to foreign bodies entering or inserting into the GI tract (3). Although this problem can be encountered in all age groups, almost $80 \%$ of the cases consist of patients in early childhood (18-48 months), and most of the cases are caused by swallowing coins, toys, crayons or pen caps. Foreign bodies can be in the form of wood pieces, glass, metal, plastic or stone / mud particles. The foreign body involved may remain asymptomatic for a long time or cause various complications such as granuloma formation, abscess formation, necrotizing fasciitis, neural injury, tendon damage and even vascular damage $(3,4)$ Imaging plays an important role not only in confirming the presence of the foreign body, but also in its

1 | $\mathrm{P}$ a g e

www.iiste.org 
exact localization. For most doctors, the first choice of imaging method is radiographs to exclude radioopaque foreign bodies. However, most wood particles are radiolucent and may be overlooked in radiographs $(2,4)$.

Foreign bodies within soft tissue can be removed relatively easily when they are radio-opaque but things become more difficult when they are not $(5,6,7)$. It is also easy to remove those that are close to the tissue surface while deep foreign bodies create more difficulty. It is necessary to pinpoint the location of the foreign body for the intervention to be successful (8).

The aim of this study was to present our cases who had presented to the emergency service or the orthopedics and general surgery outpatient departments and where a foreign body had been detected with radiological and clinical methods in various anatomical regions and then removed.

\section{Material and Method}

We retrospectively evaluated the charts of 15 patients who had presented to the Kafkas University Faculty of Medicine's General Surgery and Orthopedics and Traumatology outpatients departments or referred from the emergency service between November 2015 and July 2019 and where a foreign body had been found in various anatomical regions. A total of 15 patients where a foreign body with or without a radio-opaque appearance was detected during the clinical physical examination and with imaging methods were included in the study. Permission to conduct the study was obtained from the ethics committee (decision no. 80576354-050-99/178 dated 26-06-2019 of the Kafkas University Faculty of Medicine Ethics Committee) The demographic findings, surgical treatment used and its results, the etiological causes and postoperative complications were recorded. The patients were followed up as required.

\section{Results}

There were 8 male and 7 female patients. The mean age was 30.79 years. The symptoms included pain, redness, swelling, itching, and serous or purulent discharge in patients with foreign body in the hand, foot, elbow, arm and knee region while acute abdomen findings were present in those with a foreign body in the abdomen. The imaging methods used were conventional radiography and computed tomography. Treatments were performed under local anesthesia without adrenaline, sedation, spinal anesthesia and general anesthesia under operating room conditions and included removal of a needle (sewing needle, pin and syringe needle), pieces of glass, pieces of wood, nails, bullet fragments, buckshot and cartridge cases from bone intramedullary tissues and also an intrauterine body (IUD) from the transverse colon meso. We also observed the rectal passage with feces of an intestinal intraluminal metallic device after it was swallowed. A complication developed in only one patient where partial axonal damage of the radial nerve that innervates the forearm and wrist was encountered. The signs recovered during the six-month follow-up and the patient was able to once again use his wrist. The results have been summarized in Tables 1 to 3 . Figures 1 to 4 demonstrate the cases.

Table 1

\begin{tabular}{|c|c|c|c|c|c|c|c|c|c|c|c|c|c|}
\hline \multicolumn{2}{|c|}{ Gender } & \multicolumn{5}{|c|}{ Age Group } & \multicolumn{7}{|c|}{ Type of Foreign Body } \\
\hline Female & Male & $\begin{array}{l}0-15 \\
\text { Years }\end{array}$ & $\begin{array}{l}16-30 \\
\text { Years }\end{array}$ & $\begin{array}{l}31-45 \\
\text { Years }\end{array}$ & $\begin{array}{l}46-60 \\
\text { Years }\end{array}$ & $\begin{array}{l}61 \\
\text { Years } \\
\text { or } \\
\text { More }\end{array}$ & $\begin{array}{c}\text { PENETRATI } \\
\text { NG OR } \\
\text { CUTTING } \\
\text { (NEEDLE, } \\
\text { NAIL, ETC.) } \\
\end{array}$ & Glass & Stone & Bullet & Metal & IUD & Wood \\
\hline 7 & 8 & 3 & 5 & 4 & 3 & 0 & 5 & 3 & 1 & 2 & 2 & 1 & 1 \\
\hline
\end{tabular}

Table 2

\begin{tabular}{|c|c|c|c|c|c|}
\hline \multicolumn{5}{|c|}{ Type of Injury } \\
\hline Firearm & Work Accident & Home Accident & Traffic Accident & $\begin{array}{c}\text { Iatrogenic } \\
\text { (treatment-induced) }\end{array}$ & $\begin{array}{c}\text { By } \\
\text { swallowing }\end{array}$ \\
\hline 2 & 3 & 5 & 2 & 2 & 1 \\
\hline
\end{tabular}


Table 3

\begin{tabular}{|c|c|c|c|c|c|c|c|}
\hline \multicolumn{3}{|c|}{ Type of Anesthesia } & \multicolumn{2}{c|}{ Type of Intervention } & \multicolumn{3}{c|}{ Postoperative Complications } \\
\hline $\begin{array}{c}\text { Local Anesthesia } \\
\text { and/or Sedation }\end{array}$ & $\begin{array}{c}\text { General } \\
\text { Anesthesia }\end{array}$ & $\begin{array}{c}\text { Spinal } \\
\text { Anesthesia }\end{array}$ & $\begin{array}{c}\text { Surgical } \\
\text { Approach }\end{array}$ & $\begin{array}{c}\text { Conservative } \\
\text { Approach }\end{array}$ & Infection & $\begin{array}{c}\text { Neurovascular } \\
\text { Damage }\end{array}$ & $\begin{array}{c}\text { Soft Tissue, } \\
\text { Bone, Joint } \\
\text { Damage }\end{array}$ \\
\hline 11 & 2 & 2 & 14 & 1 & 0 & $\begin{array}{c}\text { (Radial Nerve } \\
\text { Axonal } \\
\text { Damage) }\end{array}$ & 0 \\
\hline
\end{tabular}
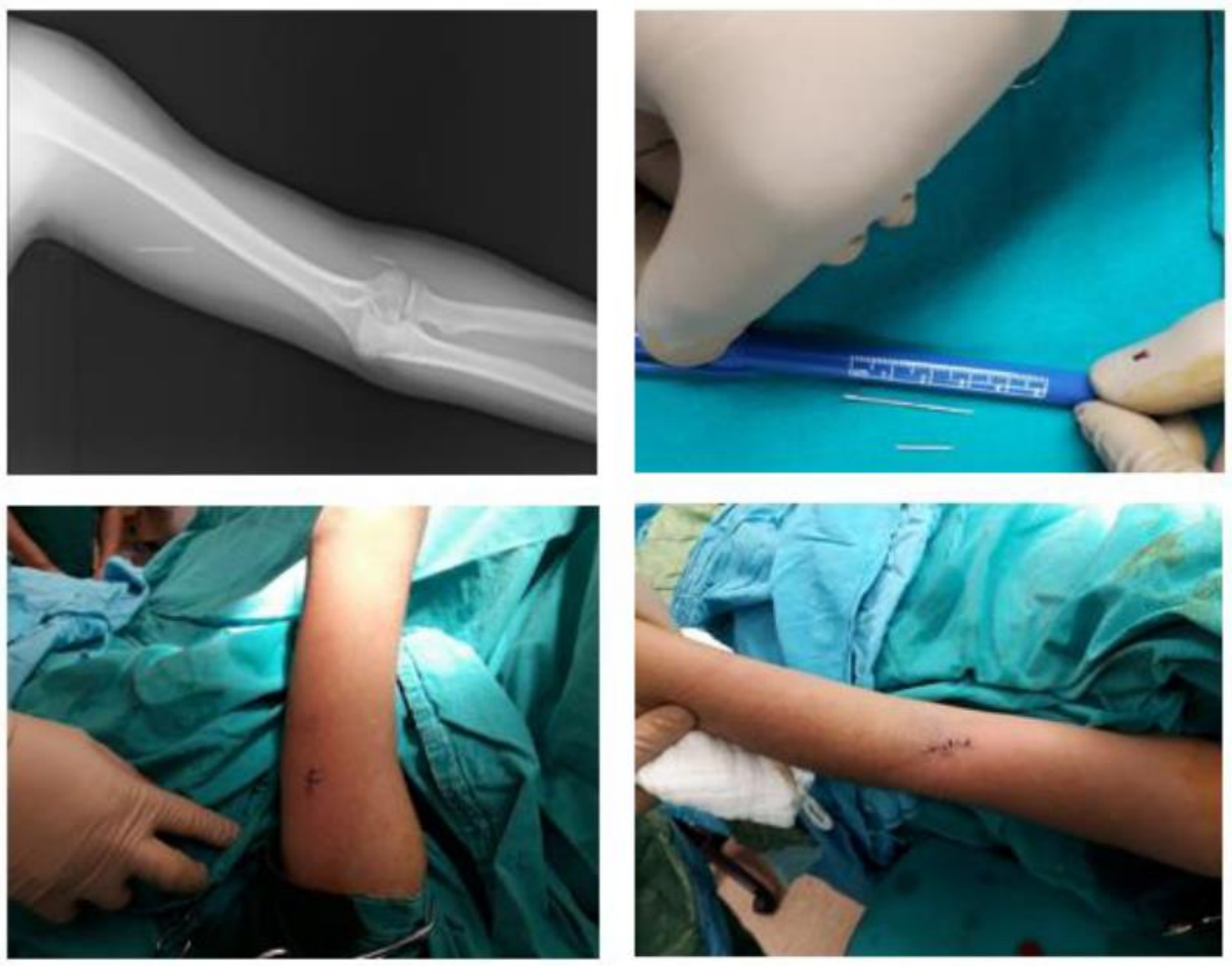

Figure 1: Broken pieces of deep injection needle within the cubital and triceps muscle in the left arm and intraoperative images
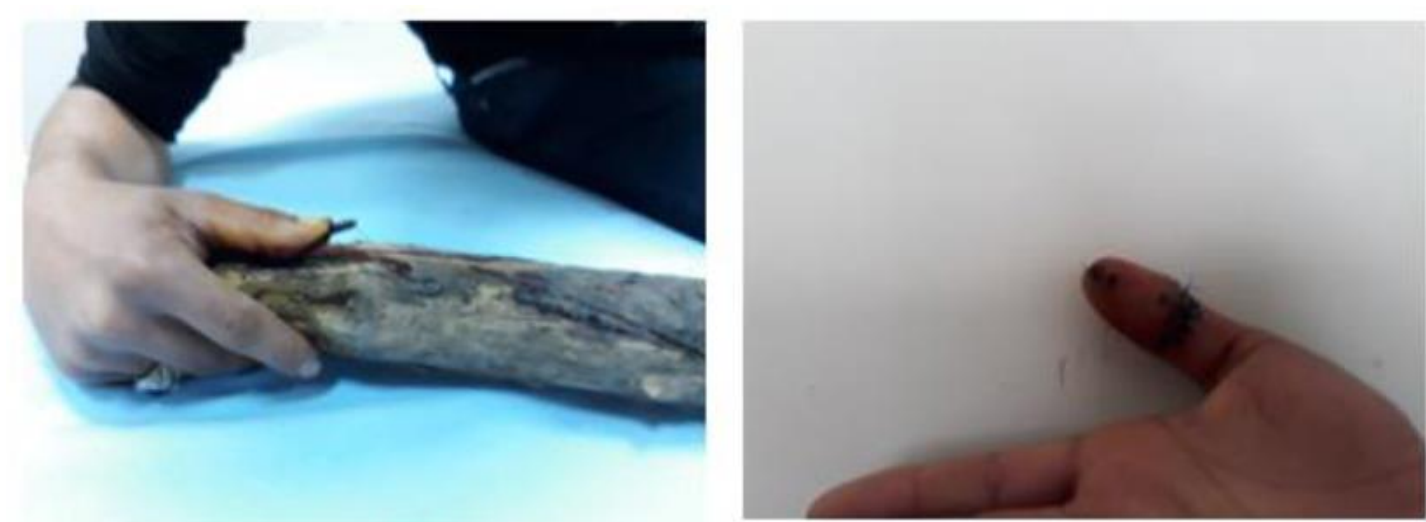

Figure 2: Preoperative and postoperative images of foreign body penetration and laceration of the right thumb 

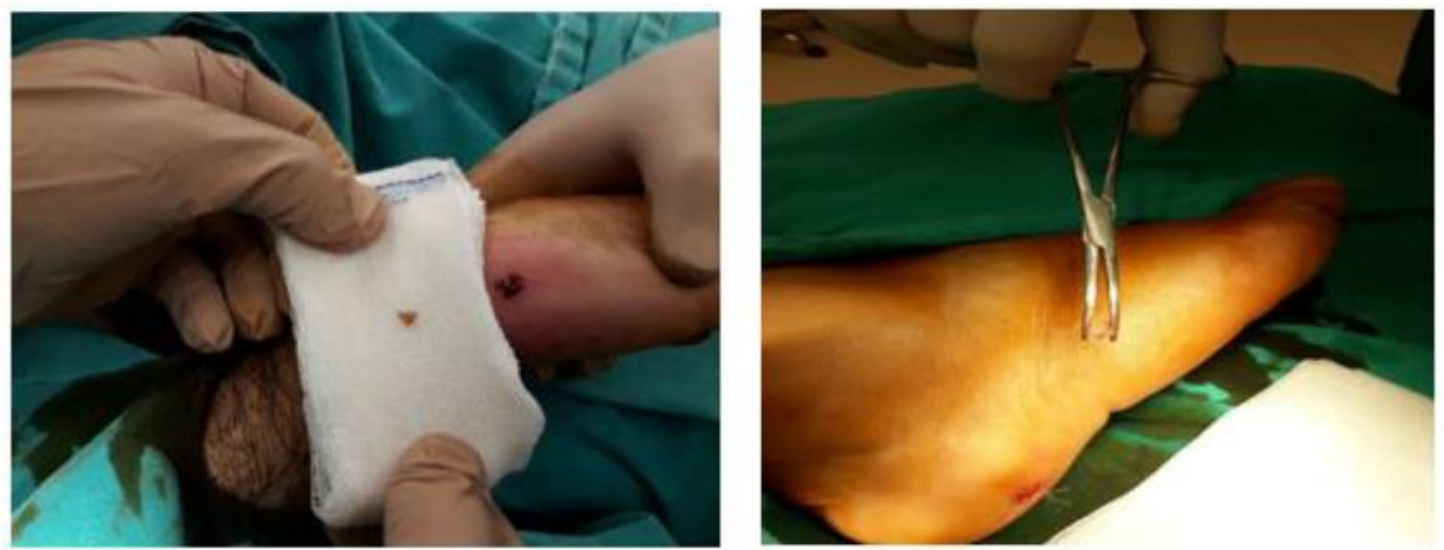

Figure 3: Intraoperative images of deep foreign body (glass) in the wrist and heel region

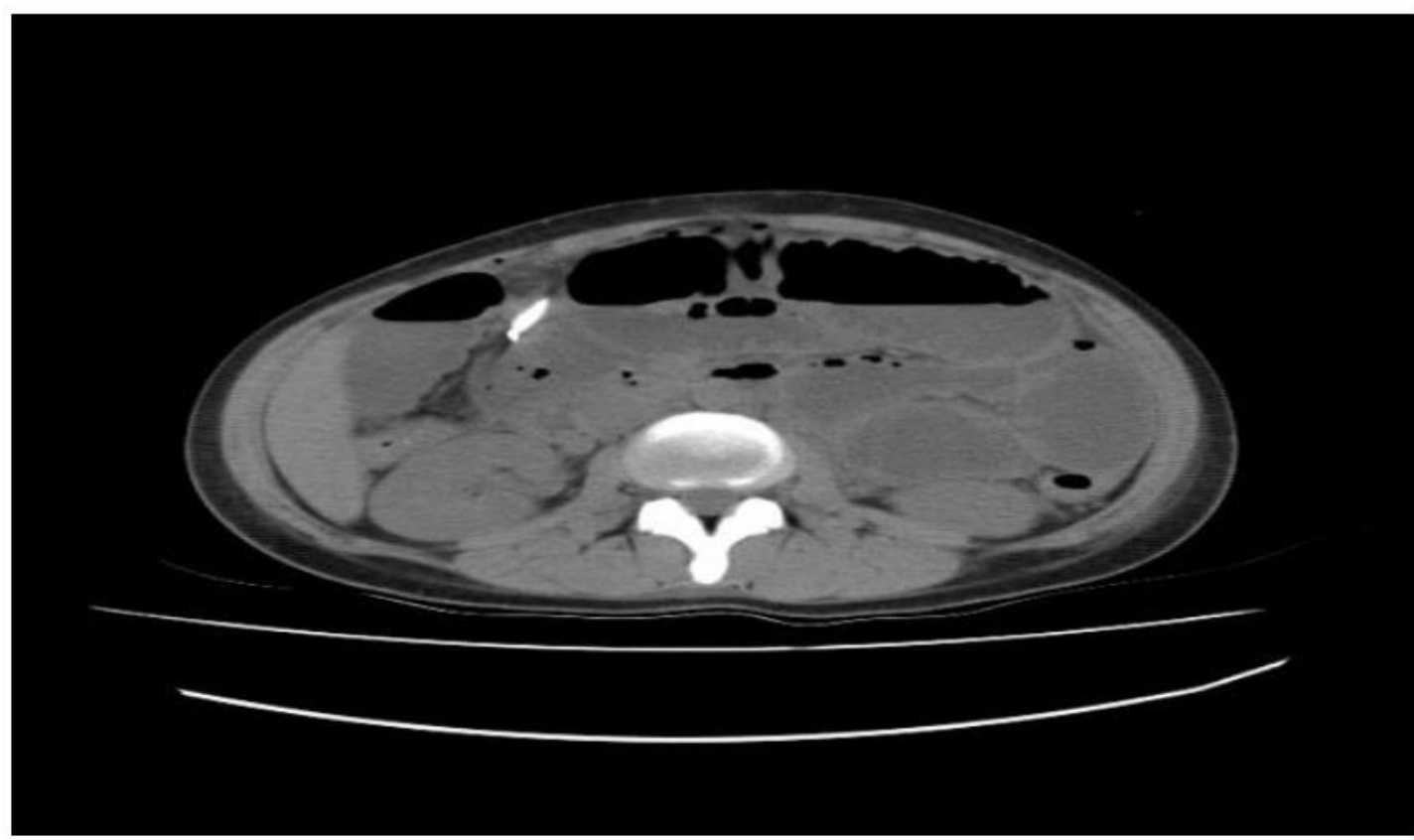

Figure 4: IUD in the transverse colon meso

\section{Discussion}

Although most foreign bodies requiring surgical intervention are radio-opaque, it is quite difficult to localize and remove them $(1,2,3,4)$. Foreign bodies within soft tissue can cause infection, inflammation and an allergic reaction while those that are within the abdomen or have caused perforation can lead to a clinical picture of acute abdomen (9). The symptoms were pain, swelling, redness, itching, serous and purulent discharge and motion limitation for foreign bodies in the hand, foot, elbow, arm and knee while the intrauterine device found in the intra-abdominal region had resulted in acute abdomen findings due to uterus perforation. A metallic foreign body was found in the intestines in one case and had cause intra-abdominal pain and guarding. The patient later passed feces through the rectal route during the 3-day follow-up, concluding the treatment. The foreign bodies can be located with various imaging methods and easily removed in such cases. Plain x-ray, computed tomography and ultrasonography can be used to screen for a suspected foreign body for these interventions $(7,8)$. It is important to plan radiographic acquisitions correctly with the extremities orientated according to the localization of the foreign body and from various directions and angles. If a radiology image is not present, the attempt to remove the foreign body may be prolonged and unsuccessful and the complication rate may increase. It is also possible to image foreign bodies from

4 | P a g e

www.iiste.org 
various angles during the surgery by using a scope. Single foreign bodies that are close to the surface and partially visible may be located and sometimes removed at the emergency service $(9,10,11,12$, 13).

It is possible to remove the various types of foreign bodies in the gastrointestinal tract using flexible endoscopy without the need for general anesthesia, especially in adult patients. However, laparotomy may be preferred if the foreign body cannot be removed or the swallowed object creates risk. Swallowing a foreign body is much more common in children than in adults. A perforation rate of less than $1 \%$ has been reported for the previous cases in the literature. This rate was higher in patients where the foreign body was sharp and had penetrating-cutting features or in those who had swallowed the foreign body $(5,6,14)$. This low rate generally indicates a conservative approach with follow-up for the surgeon. However, the risk of perforation should always be considered.

The main factors when determining the method to use for treatment are the type of foreign body and the location in the gastrointestinal system $(6,14)$. Accompanying abdominal pain, intestinal obstruction findings and gastrointestinal bleeding indicate a need for surgical intervention as the therapeutic method. Any advancement of the swallowed foreign body should be radiologically monitored; a constant position for an extended period indicates mucosa penetration which results in perforation $\operatorname{risk}(15,16,17)$. The foreign bodies located in the extremities were detected using radiographic diagnostic methods in various positions while intra-abdominal foreign bodies were located with radiography and computed tomography. We performed all the procedures under sterile conditions in the operating room, both because of the deep location of the foreign bodies in our patients and to decrease the risk of postoperative infection and intraoperative neurovascular and soft tissue injuries and also to repair any damage in these anatomical structures. We did not perform any interventions at the emergency service. The intestinal intraluminal metallic foreign body that had been swallowed in one of our cases was seen to be spontaneously discharged following radiological follow-up.

It is possible to create a smaller incision that conforms to the region and complete the procedure with minimal tissue damage when the foreign body is precisely localized(17). This also decreases the risk of postoperative complications such as infection and hematoma. We similarly matched our incisions to the foreign body location and performed the interventions with small incisions (5). None of our cases developed a postoperative infection. One of our cases suffered radial nerve axonal injury but neurofunctional recovery was ensured at the postoperative 6th month follow-up with immobilization, thermal hydrotherapy, TENS and physiotherapy. One must consider that every foreign body intervention can become quite complicated at any stage depending on the peripheral anatomy.

In conclusion, a detailed history should be obtained from all patients with a foreign body injury, followed by a physical examination and radiological and laboratory investigations. Once the foreign body is found, all surgical interventions should be performed at the operating room and under sterile conditions and the main objective of treatment should be minimizing the secondary problems that can develop following such injuries.

\section{References}

1. Johnson DG, Condon VR: Foreign bodies in the pediatric patient. Curr Probl Surg 35: 271, 1998 PMid: 9566172

2. Borgohain B, Borgohain N, Nandique A, Gogoi PJ. Case report and brief review of literature on sonographic detection of accidentally implanted wooden foreign body causing persistent sinus. Crit Ultrasound J. 2012;4:10-13.

3. Anderson KL, Dean AJ. Foreign bodies in the gastrointestinal tract and anorectal emergencies. Emerg Med Clin North Am. 2011;29:369-400, ix.

4. Erten EF, Karaman A, Karaman İ, Çavuşoğlu YH, Özgüner İF, Erdoğan D. Journal of Pediatric Surgery 24(3):141-143, 2010doi:10.5222/JTAPS .2010.141 A rare complication of trauma: Residual soft-tissue foreign body

5. Çinçin TG. The Journal of Kartal Traınıng and Research Hospital 2005 16(2) 59-62 Removal Of Radiopaque Foreign Bodies Embedded Withın The Soft Tissues By Stereotaxic Approach

5 | P a g e

www.iiste.org 
6. Velitchkov NG, Grigorov GI, Losanoff JE, et al. Ingested foreign bodies of the gastrointestinal tract: retrospective analysis of 542 cases. World J Surg. 1996;20(8):1001-5.

7.Yıldırım C, Sözüer E M , Avşaroğulları L,Karaoğlu S, Günay N. Turkısh Journal of Trauma Emergency Surgery.1999; 5(3): 213-216 Removal of Radiopaque Foreign Bodies Ambedded in Soft Tissues by Stereotaxic Approach

8.Russell RC, Williamson DA, Sullivan JW, Suchy H,Suliman O. Detection of foreign bodies in the hand. J Hand Surg 1991;16(1):2-11.

9. Bonatz E, Robbin ML, Weingold MA. Ultrasound for the diagnosis of retained splinters in the soft tissue of the hand. Am J Orthop 1998;27(6):455-9.

10. Roobottom CA, Weston MJ. The detection of foreign bodies in soft tissue - comparison of conventional and digital radiography. Clin Radiol 1994;49(5):330-2.

11. Jimenez-Fuertes M1, Moreno-Posadas A2, Ruíz-Tovar Polo J2, Durán-Poveda M2. Liver abscess secondary to duodenal perforation by fishbone: Report of a case. Rev Esp Enferm Dig. 2016 Jan;108(1):42.

12.Guillén-Paredes MP, Lirón-Ruiz R, Torralba-Martínez JA, et al. Perforación intestinal por ingesta de espina de pescado. Importancia del diagnóstico por imagen. Rev Esp Enferm Dig 2010;102:569-70.

13. Lunsford KE, Sudan R. Small bowel perforation by a clinically unsuspected fish bone: Laparoscopic treatment and review of literature. J Gastrointest Surg 2012;16:218-22. DOI: $10.1007 / \mathrm{s} 11605-011-1610$

14. Başpınar İ, Şahin S, Erdoğan G. Acute mechanical intestinal obstruction after ingestion of foreign bodies: a case report. Turkish Journal of Trauma \& Emergency Surgery. 2010;16(1):924.

15. Shivakumar AM, Naik AS, Prashanth KB, et al. Foreign body in upper digestive tract. Indian J Pediatr. 2004;71(8):689-93

16. Nishimoto Y, Suita S, Taguchi T, et al. Hepatic foreign body - a sewing needle - in a child. Asian J Surg. 2003;26(4):231-3.

17.Yücel M, Çalışkan M, Şişik A et al. Penetratıng Anterıor Abdomınal Stab İnjury Dokuz Eylul University Faculty of Medicine Journal. 2011;25(3):175-80. 